TITLE:

\title{
Asymmetrical morphology and growth of the hermit crab Pagurus filholi (Decapoda, Anomura, Paguridae) reared in non-dextral shell conditions
}

\author{
AUTHOR(S): \\ Imafuku, Michio; Ikeda, Hisakazu
}

\section{CITATION:}

Imafuku, Michio ... [et al]. Asymmetrical morphology and growth of the hermit crab Pagurus filholi (Decapoda, Anomura, Paguridae) reared in non-dextral shell conditions. Crustaceana 2014, 87(4): 476-488

ISSUE DATE:

2014-05-06

URL:

http://hdl.handle.net/2433/187807

\section{RIGHT:}

(c) 2014 Brill.; この論文は出版社版でありません。引用の際には出版社 版をご確認ご利用ください。; This is not the published version. Please cite only the published version. 


\section{ASYMMETRICAL MORPHOLOGY AND GROWTH OF A HERMIT CRAB PAGURUS}

FILHOLI (DECAPODA, ANOMURA, PAGURIDAE) REARED IN NON-DEXTRAL

\section{SHELL CONDITIONS}

BY

\section{MICHIO IMAFUKU ${ }^{1,3}$ ) and HISAKAZU IKEDA ${ }^{2}$ )}

$\left.{ }^{1}\right)$ Graduate School of Science, Kyoto University, Sakyo, Kyoto, 606-8502 Japan

2) 2581 Shirahama, Nishimuro-gun, Wakayama, 649-2211 Japan

${ }^{3}$ ) Corresponding author; postal address: 619-15 Shizuichi-Ichihara, Sakyo, Kyoto, 601-1123,

Japan; Tel. and Fax: +81-75-741-1322; e-mail: imafuku@kyoto.zaq.ne.jp 


\begin{abstract}
The body of a hermit crab shows asymmetrical morphology, which may be related
\end{abstract} to utilization of the dextral shell. To examine the effect of the shell, we reared Pagurus filholi (De Man, 1887) from the glaucothoe stage to full-sized adults, in a sinistral shell, in a straight tusk shell, without a shell, and in a normal dextral shell as a control. Body parts that show the most conspicuous asymmetry, uropods, pleopods and chelipeds, were checked at the time of the shedding of exuviae during rearing. No inversion of laterality on these characters was observed. However, in crabs subjected to conditions other than a dextral shell, the otherwise rather short right uropod became somewhat extended, and in those reared in sinistral shells, the right major cheliped was more enlarged.

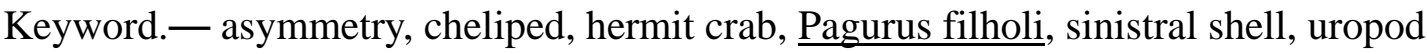

\title{
INTRODUCTION
}

Asymmetrical morphology is widely known in crustaceans, especially on the chelipeds of decapods. Heterochely is described in brachyuran crabs of the Ocypodidae (Crane, 1975; Yamaguchi, 1977; Barnwell, 1982; Trott, 1987; Jaroensutasinee \& 
Jaroensutasinee, 2004), the Portunidae (Hamilton et al., 1976; Abby-Kalio \& Warner, 1989;

Ladle \& Todd, 2006), the Xanthidae (Tweedie, 1950; Yamaguchi et al., 1976; Shigemiya,

2003) and the Calappidae (Shoup, 1968; Ng \& Tan, 1985), in shrimps of the Alpheidae

(Stockard, 1910; Young et al., 1994; Anker et al., 2006), in prawns of the Palaemonidae

(Davis, 1987; Mariappan et al., 2000) and in lobsters of the Nephropidae (Govind \& Pearce,

1986; Govind, 1989).

In anomuran hermit crabs, Paguroidea, heterochely is genetically fixed, and used as

one of keys for taxonomy of this group (Wicksten, 2012); most members of families

Paguridae and Parapaguridae possess a larger cheliped on the right whereas members of family Diogenidae on the left or have symmetrical chelipeds (Miyake, 1978). Hermit crabs are especially interesting, as they usually occupy coiled gastropod shells. The length of their uropods is usually skewed to the left (Jackson, 1913; McLaughlin, 1980; Barnes, 1980; Imafuku \& Ando, 1999), though they may be symmetrical in crabs that inhabit worm tubes or tusk shells (McLaughlin \& Lemaitre, 1993; Wicksten, 2012). Unpaired pleopods are located on the left side of the body over different taxonomic groups (Miyake, 1978; McLaughlin, 1980; Barnes, 1980). Asymmetrical pleopods are also observed for such anomuran crabs as robber crabs, Birgus latro (Linnaeus, 1767), and lithodoid crabs that do not occupy snail 
shells (Miyake, 1978). Further, asymmetry is observed in the internal morphology of hermit crabs; the sternal artery that starts from the posterior end of the heart locating just above the alimentary canal runs on the left side of the canal toward the ventral nerve cord (Imafuku, 1993). These characteristics are thought to be adaption to inhabit a dextral shell.

Should these characteristics observed in hermit crabs be modified or reversed by forcing them to grow in a sinistral shell or non-dextral shell from the larval stage on? To answer this question, we reared individuals of Pagurus filholi (De Man, 1887) for five years with a sinistral shell, with a straight tusk shell or without a shell. This species is distributed widely over Japan, Korea and Formosa (Miyake, 1978). They live in intertidal zones, occupying shells of 16 gastropod species (Imafuku, 1984), and show adaptive behaviour on asymmetrical shells (Imafuku, 1994). Their breeding seasons is from autumn to spring (Imafuku, 1986).

\section{MATERIAL AND METHODS}

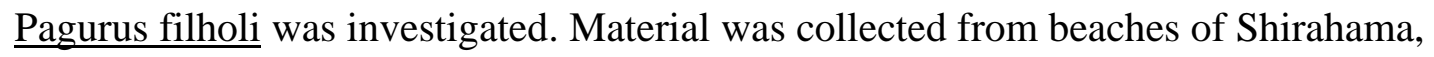

Wakayama Pref., Japan $\left(33^{\circ} 41^{\prime} \mathrm{N} 135^{\circ} 20^{\prime} \mathrm{E}\right)$. 


\section{Morphological measurements}

The species Pagurus filholi, has the major cheliped on the right. To explore the part that showed the most conspicuous asymmetry, lengths of segments from the dactylus to the merus of five pereiopods and widths of the chelipeds were measured for two sample individuals collected in fields, and the asymmetry index (AI) was calculated following Van Valen (1962); $\mathrm{AI}=(\mathrm{L}-\mathrm{R}) /(\mathrm{L}+\mathrm{R})$, where $\mathrm{L}$ and $\mathrm{R}$ are left and right measurements, respectively. This value fluctuates between +1 (left longer) and -1 (right longer) with 0 indicating perfect symmetry. The AI of the cheliped width was the largest in absolute value, and thus this part was adopted for the following analysis. Further, the uropods which were expected to largely be affected by shell-inhabitation were also examined.

\section{Field individuals}

Prior to rearing experiments, the asymmetry index of cheliped and uropod of field crabs was determined. Forty crabs of each sex were collected from the beach on 31 December 1989. Shield lengths of these crabs (2.0-5.5 mm) approximately overlapped those of crabs examined in the rearing experiment (1.5-5.7 $\mathrm{mm})$. 


\section{Rearing experiment}

Zoeae hatched on 8 February 1989 from three females were reared with rotifers and nauplii of brine shrimp in a plastic tray (165 $\mathrm{mm}$ in diameter, $40 \mathrm{~mm}$ deep). They metamorphosed into megalopae from March to April, and then were divided into four groups; with dextral shells (group D), with sinistral shells (group S), with straight tusk shells (group T), and without shells (group N).

Megalopae and succeeding crabs in group D were provided with minute shells of Homalopoma nocturnum (Gould, 1861) and Iwakawatrochus urbanus (Gould, 1861), small shells of Echinolittorina radiata (Souleyet in Eydoux \& Souleyet, 1852) and Cantharidus spp., and large shells of Monodonta confusa Tepparone-Canefri, 1874 and Lunella coreensis (Récluz, 1853), depending on crab size. Small crabs in group S were provided with sinistral shells of some species belonging to Triphoridae and terrestrial Clausiliidae. Minute individuals in this group were provided with apexes cut from the spire of these species. Large individuals were provided with shells of Antiplanes vinosa (Dall, 1874). Minute crabs in group $\mathrm{T}$ were provided with suitable lengths of thin glass tubes built by pulling glass tubes over a flame, and small and large crabs were provided with cut pieces of straight shells of 
such dentaliid species as Episiphon makiyamai (Kuroda et Kikuchi, 1933), Dentalium octangulatum Donovan, 1804 and Pictodentalium vernedei (Hanley in Sowerby, 1860).

Since mortality was high in the megalopal and young crab stages, all crabs were reared in a single tray. On 4 February 1990, each crab was transferred to an individual tray (135 $\mathrm{mm}$ in diameter, $40 \mathrm{~mm}$ deep), with five to six crabs in each group. Then all exuviae were collected and preserved in 70\% ethanol until 9 November 1994 when only two crabs, both in tusk shells, were alive.

Crabs were provided with field-collected pebbles covered with micro algae as food. Pebbles and sea water were exchanged every one to three days in summer and three to seven days in winter. They were kept at natural temperatures. The number, sex and longevity of the reared crabs are shown in table I.

\section{Statistics}

Regression analysis was used to examine the effect of crab size on the uropods and chelipeds. For comparison of effects of shell types on the morphology of crabs, a Tukey-Kramer's HSD test was used at a significance level of $\mathrm{p}=0.05$. JMP version 5.1.1 software was adopted. 


\section{RESULTS}

Crabs from the wild population

Uropod

The asymmetry index (AI) of the uropod of 80 field crabs was scattered between

0.2 and 0.37 with an average of 0.268 (fig. 1A). This indicates that the right uropod is $42 \%$ shorter than the left one. The regression line of females suggests an effect of the crab size on AI. The slope of the regression line of females significantly differed from zero $(t=3.29, p=$ 0.002), whereas that of males did not $(t=-0.58, \mathrm{p}=0.564)$.

A rise of AI with crab size in females is attributable either to a relatively large extension of the left uropod or a relatively strong suppression of growth of the right uropod.

The growth rate of uropod in females was compared with that in males by multiple regression analysis. The results showed that it was significantly lower on the right side (RF vs. RM in fig. $1 \mathrm{~B}, \mathrm{t}=-2.63, \mathrm{p}=0.010$ ), but not different on the left side (LF vs. $\mathrm{LM}, \mathrm{t}=-0.11, \mathrm{p}=$ 0.912). Thus, the growth of the right uropod is significantly slower in females.

Cheliped 
Slopes of the regression line of AI of the cheliped width did not differ from zero in either males $(t=-1.61, p=0.117)$ or females $(t=1.79, p=0.081)$ (fig. 1C). The average AI was -0.286 in males and -0.236 in females, and the difference was significant ( $\mathrm{t}$-test, $\mathrm{t}=6.88$, $\mathrm{p}<0.0001)$. The right cheliped was $80.1 \%$ larger than the left one in males and $61.8 \%$ in females.

Regression lines of cheliped widths against crab size shown in fig. 1D suggest a higher growth rate of the right cheliped in males than in females. Difference of growth rate was significant in the right cheliped ( $R F$ vs. $R M, t=-4.24, p<0.0001)$ but not in the left one (LF vs. $L M, t=-1.95, p=0.055$ ), indicating a significant rapid growth of the right major cheliped in males.

Rearing experiment

\section{Uropods}

In each group of shell type, 5 or 6 crabs survived for at least 600 days of culture, and sex was biased to females (table 1).

The AI and length of uropods in respective groups are shown in fig. 2. In this figure, all exuviae derived from the same individuals are plotted as independent points. The 
asymmetry index is nearly constant. This is the case for female crabs in group D (open circles in fig. 2A), which clearly differs from the result of female field crabs (fig. 1A). The difference seems to be attributable to the difference in rearing conditions as described in the Discussion.

The crabs provided with dextral shells had higher AIs than those in the other groups both in females (fig. 2A) and males (fig. 2B). The AIs were compared among crabs in different shell groups by a multiple comparison test. Firstly, residues from a regression line for all crabs including different groups, were calculated, and then averaged for the same individual to obtain an individual value. The individual values were compared among groups. Fig. 4 shows data from males and females compiled, because not many crabs were reared. Crabs provided with a dextral shell showed a significantly high value, thus stronger asymmetry (fig. 4A). This significant difference is attributable to a significant shortening of the right uropod in group D (figs. 2C, D, 4B). On the other hand, left uropods showed no difference with the group (figs. 2E, F, 4C). Thus, crabs without a shell or provided with non-dextral shells possess more symmetrical uropods based on lengthening of the right one.

Cheliped 
The AI and width of chelipeds are shown in fig. 3. The AI slightly increased with crab size, and that in group $\mathrm{S}$ (solid circle in fig. 3A) tended to be scattered and low. A multiple comparison test indicated that $\mathrm{AI}$ in group $\mathrm{S}$ was significantly different from that in groups $\mathrm{N}$ and D (fig. 4D). Thus, crabs reared with sinistral shells have strongly skewed chelipeds. This significant difference is caused by the relatively enlarged right cheliped in group S (fig. 4E).

Pleopod

Unpaired pleopods that are normally located on the left side of the body did not change in their position by rearing crabs with non-dextral shells.

Growth

In the present study, crabs were reared for 2-5 years. The longest survivor was a female that occupied a tusk shell for 2364 days (6.5 years) until 31 July 1995 when it escaped from the rearing tray. The growth rate and seasonal fluctuation of moulting of the crabs reared were analysed.

Shield lengths were plotted against days of rearing (fig. 5). For comparison of 
growth rate, shield lengths (SL) of exuviae derived from the same individual were approximated to a function: $\mathrm{SL}=\mathrm{a} * \log ($ Day $)+\mathrm{b}$, where Day is the number of days after the initiation of exuvia collection. The slope (a) did not show any significant difference among groups. Similarly, moulting interval did not differ with the shell-type group, and was $64 \pm 10$ days on average for all the reared crabs.

Seasonal trends of growth rate, moulting frequency and growth per moult are shown in fig. 6. Growth rate was highest from spring to summer, moulting frequency in summer, and as a result, a peak of the growth rate per moult falls in the end of winter.

\section{DISCUSSION}

Many hermit crab species are known to have asymmetrical or left-skewed uropods.

In the shell, the right-side of the body of inhabitants is pressed strongly to the inner surface of the shell they occupy. The right uropod of the field crabs, Pagurus filholi, was $42 \%$ shorter on average than the left one. However, field females had more skewed uropods as they grew. This may be because the females carry eggs attached to the pleopods restricted to the left side of the body, which should more strongly press the abdomen to the right.

On the other hand, females under rearing conditions did not have the skewed 
uropods seen in the field females. In rearing conditions, they were maintained solitarily and did not copulate or lay eggs. This seems to be the cause of the less strongly skewed uropods in the reared females.

Crabs reared with a non-dextral shell or without a shell developed a less asymmetrical uropod than those with a normal dextral shell. Crabs forced to live in a sinistral shell did not show reversed asymmetry. These facts indicate that the asymmetry of uropods is genetically determined and phenotypic plasticity is exhibited in its degree.

Gherardi \& McLaughlin (1995) examined the effects of housing on the morphology of the hermit crab Discorsopagurus schmitti (Stevens, 1925) which has a symmetrical body shape due to inhabiting worm-tubes and tusk shells. They reared juveniles of this species with spiral shells, worm-tubes and without housing, and found a slight difference in pleopods, but not in uropodal symmetry. As the examined crabs were limited to the first two juvenile stages following the megalopal stage, it may be that young stages were not strongly influenced.

A certain degree of morphological modification is known to occur by utilization of different shell shapes in field hermit crabs. In Paguristes seminudus Stimpson, 1858, AI of the uropod was 0.27 for specimens living in gastropod shells, whereas it was $0.02-0.08$ for those living in tusk shells (Imafuku \& Ando, 1999). For morphological modification of 
hermit crabs, it is possible that the body fits the shell morphology immediately after moulting when the body is soft (Elwood et al., 1979).

Heterochely is widely known in hermit crabs, but handedness is not related to inhabitation of dextral shells, because some species are right-handed and some are left-handed, as mentioned in Introduction. However, when crabs of Pagurus filholi belonging to family Paguridae, members of which are right-handed, were reared in sinistral shells, they developed more enlarged right chelipeds (fig. 4D, 4E). Why did such an unexpected phenomenon occur? Modification of uropodal asymmetry would be expected, because the organ is located at the posterior end of the body under strong influence of the shell. On the other hand, chelipeds are usually held outside of the shell. However, they may be affected, when the crab withdraws into the shell. One explanation of cheliped modification in crabs with a sinistral shell might be that the right cheliped receives the stress in a normal dextral shell, but not in a sinistral shell, which promotes its enlargement. This explanation, however, seems to be inadequate, because crabs maintained without a shell did not develop enlarged right chelipeds, even though they then receive no more stress on the right cheliped. An alternative explanation may be that a stress on the left cheliped that is newly introduced by sinistral-shell occupation leads to an enlargement of the right cheliped. This "contralateral" 
explanation may be supported by the development of heterochely in the lobster Homarus americanus H. Milne-Edwards, 1837 by Govind \& Pearce (1986). In the juvenile stage of the lobster, when one claw is subjected to exercise, that claw develops into a crusher. When both claws are left intact without exercise, they develop into cutters. When both claws are subject to exercise, they develop into cutters, but not into crushers. This phenomenon is explained as follows. Exercise has two functions, one is to lead the claw into a crusher, and the other is to suppress the opposite claw to develop into a crusher, and the latter is dominant. That is, a stimulus that occurs on one side of a paired claw has an effect on the other side. A similar phenomenon may have occurred in our hermit crabs.

In nature, hermit crabs that normally carry a shell are hardly found in naked state.

Only occasionally does one crab live together with another crab in a single shell (Imafuku, 1983). These facts indicate that housing is inevitable for the hermit crab to survive in nature.

On the other hand, crabs without a shell in our experiment could survive normally, without any delay of growth, for at least five years. This clearly indicates that a shell is not necessary for normal growth or feeding, but is necessary for protection from predation.

\section{ACKNOWLEDGEMENTS}


We thank Akira Mori of Kyoto University for advice on statistics, Yuriko Ikeda for assisting in long term rearing of hermit crabs, and Sumiko Kaihara for carefully reading the manuscript.

\section{REFERENCES}

Abby-Kalio, N.J. \& G.F. Warner, 1989. Heterochely and handedness in the shore crab Carcinus maenas (L.) (Crustacea: Brachyura). Zool. J. Linn. Soc., Lond., 96: 19-26.

Anker, A., S.T. Ahyong, P.Y. Noël \& A.R. Palmer, 2006. Morphological phylogeny of alpheid shrimps: parallel preadaptation and the origin of a key morphological innovation, the snapping claw. Evolution, 60: 2507-2528.

Barnes, R.D., 1980. Invertebrate Zoology (ed. 4): 1-1089. (Saunders, Philadelphia).

Barnwell, F.H., 1982. The prevalence of male right-handedness in the Indo-West Pacific fiddler crabs Uca vocans (Linnaeus) and U. tetragonon (Herbst) (Decapoda: Ocypodidae). J. Crust. Biol., 2: 70-83.

Crane, J., 1975. Fiddler crabs of the world. Ocypodidae: genus Uca: 1-736. (Princeton University Press, New Jersey).

Davis, T.A., 1987. Laterality in Crustacea. Proc. Indian nat. Acad. Sci., (B) 52: 47-60. 
Elwood, R.W., A. McLean \& L. Webb, 1979. The development of shell preferences by the hermit crab Pagurus bernhardus. Anim. Behav., 27: 940-946.

Gherardi, F. \& P.A. McLaughlin, 1995. Larval and early juvenile development of the tube-dwelling hermit crab Discorsopagurus schmitti (Stevens) (Decapoda: Anomura: Paguridae) reared in the laboratory. J. Crust. Biol. 15: 258-279.

Govind, C.K., 1989. Asymmetry in lobster claws. Am. Sci., 77: 468-474.

Govind, C.K. \& J. Pearce, 1986. Differential reflex activity determines claw and closer muscle asymmetry in developing lobsters. Science, 233: 354-356.

Hamilton, P.V., R.T. Nishimoto \& J.G. Halusky, 1976. Cheliped laterality in Callinectes sapidus (Crustacea: Portunidae). Biol. Bull., 150: 393-401.

Imafuku, M., 1983. Two hermit crabs inhabiting a single gastropod shell. J. Ethol., 1: 113-114.

— - 1984. Quality of shells occupied by the hermit crab Pagurus geminus: How many hermit crabs are satisfied with their shells? J. Ethol., 2:31-36.

— - 1986. Sexual discrimination in the hermit crab Pagurus geminus. J. Ethol., 4:39-47.

— -1993 . Observations on the internal asymmetry of the sternal artery and the cheliped asymmetry in selected decapod crustaceans. Crust. Res., No. 22: 35-43.

— - 1994. Response of hermit crabs to sinistral shells. J. Ethol., 12:107-114. 
Imafuku, M. \& T. Ando, 1999. Behaviour and morphology of pagurid hermit crabs

(Decapoda, Anomura) that live in tusk shells (Mollusca, Scaphopoda). Crustaceana, 72:

129-144.

Jackson, H.G., 1913. Eupagurus. Proc. Trans. Liverpool Biol. Soc., 27: 495-573.

Jaroensutasinee, M. \& K. Jaroensutasinee, 2004. Morphology, density, and sex ratio of fiddler crabs from Southern Thailand (Decapoda, Brachyura, Ocypodidae). Crustaceana, 77: 533-551.

Ladle, R.J. \& P.A. Todd, 2006. A developmental model for predicting handedness frequencies in crabs. Acta Oecol., 30: 283-287.

Mariappan, P., C. Balasundaram \& B. Schmitz, 2000. Decapod crustacean chelipeds: an overview. J. Biosci., 25: 301-313.

McLaughlin, P.A., 1980. Comparative morphology of recent Crustacea: 1-177. (Freeman and Company, San Francisco).

McLaughlin, P.A. \& R.L. Lemaitre, 1993. A review of the hermit crab genus Paguritta (Decapoda: Anomura: Paguridae) with description of three new species. Raffles Bull. Zool., 41: 1-29.

Miyake, A., 1978. The crustacean anomura of Sagami Bay: 1-200. (Biol. Lab., Imperial 
Household, Tokyo).

Ng, P.K.L. \& L.W.H. Tan, 1985. 'Right handedness' in heterochelous calappoid and xanthoid crabs - suggestion for a functional advantage. Crustaceana, 49: 98-100.

Shigemiya, Y., 2003. Does the handedness of the pebble crab Eriphia smithii influence its attack success on two dextral snail species? J. Zool., Lond., 260: 259-265.

Shoup, J.B., 1968. Shell opening by crabs of the genus Calappa. Science, 160: 887-888.

Stockard, C.R., 1910. The question of reversal of asymmetry in the regenerating chelae of Crustacea. Biol. Bull., 19: 243-255.

Trott, T.J., 1987. The prevalence of left-handedness in the painted ghost crab Ocypode gaudichaudii H. Milne Edwards and Lucas (Decapoda, Brachyura, Ocypodidae). Crustaceana, 52: 213-215.

Tweedie, M.W.F., 1950. The fauna of the Cocos-Keeling Islands, Brachyura and Stomatopoda. Bull. Raffles Mus., 22: 105-148.

Van Valen, L., 1962. Study of fluctuating asymmetry. Evolution, 16: 125-142.

Wicksten, M.K., 2012. Dacapod Crustacea of the Californian and Oregonian zoogeographical provinces. Zootaxa, 3371: 1-307.

Yamaguchi, T., 1977. Studies on the handedness of the fiddler crab, Uca lactea. Biol. Bull., 
152: 424-436.

Yamaguchi, T., M. Takeda \& K. Tokudome, 1976. A list of crabs collected in the vicinity of the Aitsu Marine Biological Station and a preliminary report on the cheliped asymmetry of the crabs. Calanus, No.5: 31-46. (in Japanese)

Young, R.E., J. Pearce \& C.K. Govind, 1994. Establishment and maintenance of claw bilateral asymmetry in snapping shrimps. J. Exp. Zool., 269: 319-326. 
[Figure legend]

Fig. 1. Asymmetry index (top panels) and the size (bottom panels) of uropods and chelipeds

of hermit crabs, Pagurus filholi (De Man, 1887), collected in the field. Abbreviations are:

F, female; M, male; L, left; and R, right.

Fig. 2. Asymmetry index (left panels) and the size of right side (middle panels) and left side

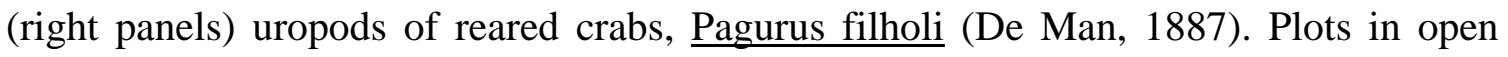
circles, triangles, solid circles and crosses are data from crabs reared with a dextral shell (D), tusk shell (T), sinistral shell (S) and without a shell $(\mathrm{N})$, respectively. Units of ordinate of panels $\mathrm{C}-\mathrm{F}$ are in $\mathrm{mm}$.

Fig. 3. Asymmetry index (left panels) and the size of right side (middle panels) and left side (right panels) chelipeds of reared crabs, Pagurus filholi (De Man, 1887). Plots in open circles, triangles, solid circles and crosses are data from crabs reared with a dextral shell (D), tusk shell (T), sinistral shell (S) and without a shell (N), respectively. Units of ordinate of panels C-F are in $\mathrm{mm}$.

Fig. 4. Comparison of asymmetry index and size of uropods and chelipeds of Pagurus filholi (De Man, 1887) among shell groups. Group names, and the numbers (in parentheses) of individuals used for these comparisons are shown at the bottom. The mean (histogram) 
and standard deviation (vertical bar) of residues (see text) are shown for each group. The groups shown in black and white histograms are significantly different, and those in grey histograms are not different from either group. W and G mean white and grey histograms, respectively.

Fig. 5. Shield lengths of exuviae of Pagurus filholi (De Man, 1887) collected after the initiation of collection, on 361th day of hatching. A logarithmic regression line is shown for each group.

Fig. 6. Monthly trend of growth rate and moulting of Pagurus filholi (De Man, 1887). White, grey and black bars indicate the growth rate per month $(\mathrm{X} 0.1 \mathrm{~mm})$, number of moulting per month, growth rate per moult $(\mathrm{mm})$, respectively. Top line indicates monthly average temperatures from February 1989 to November 1994. 


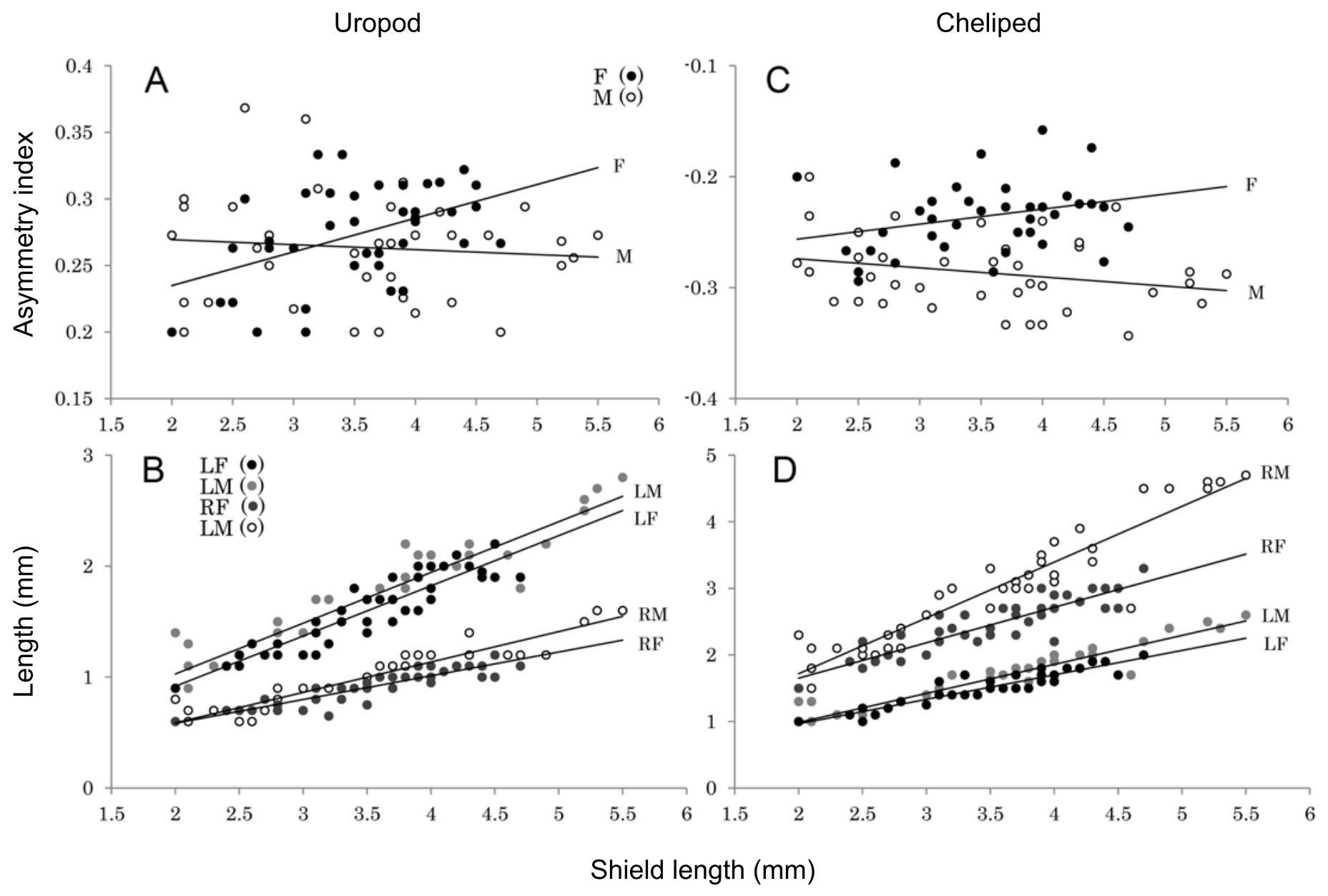




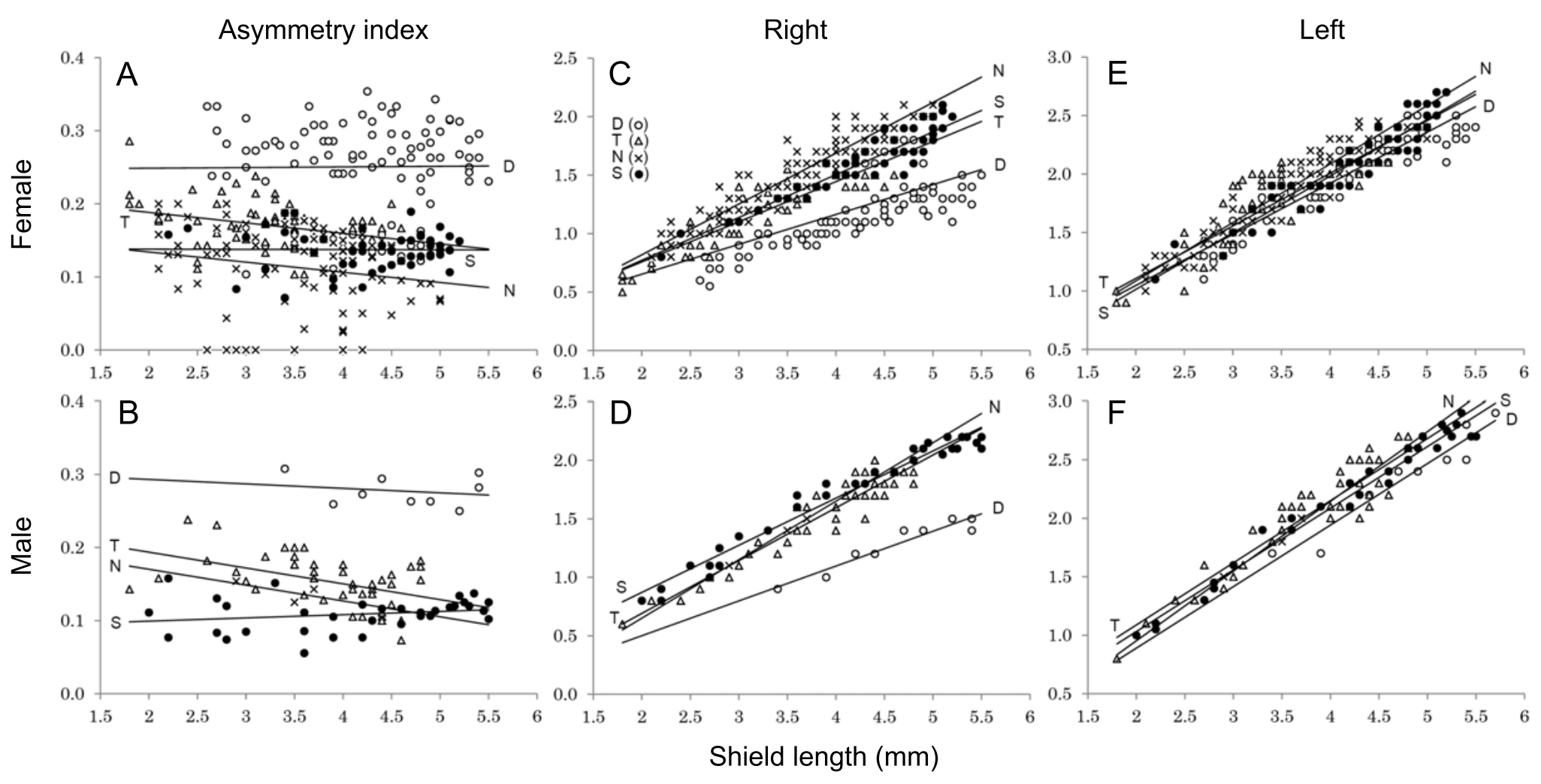




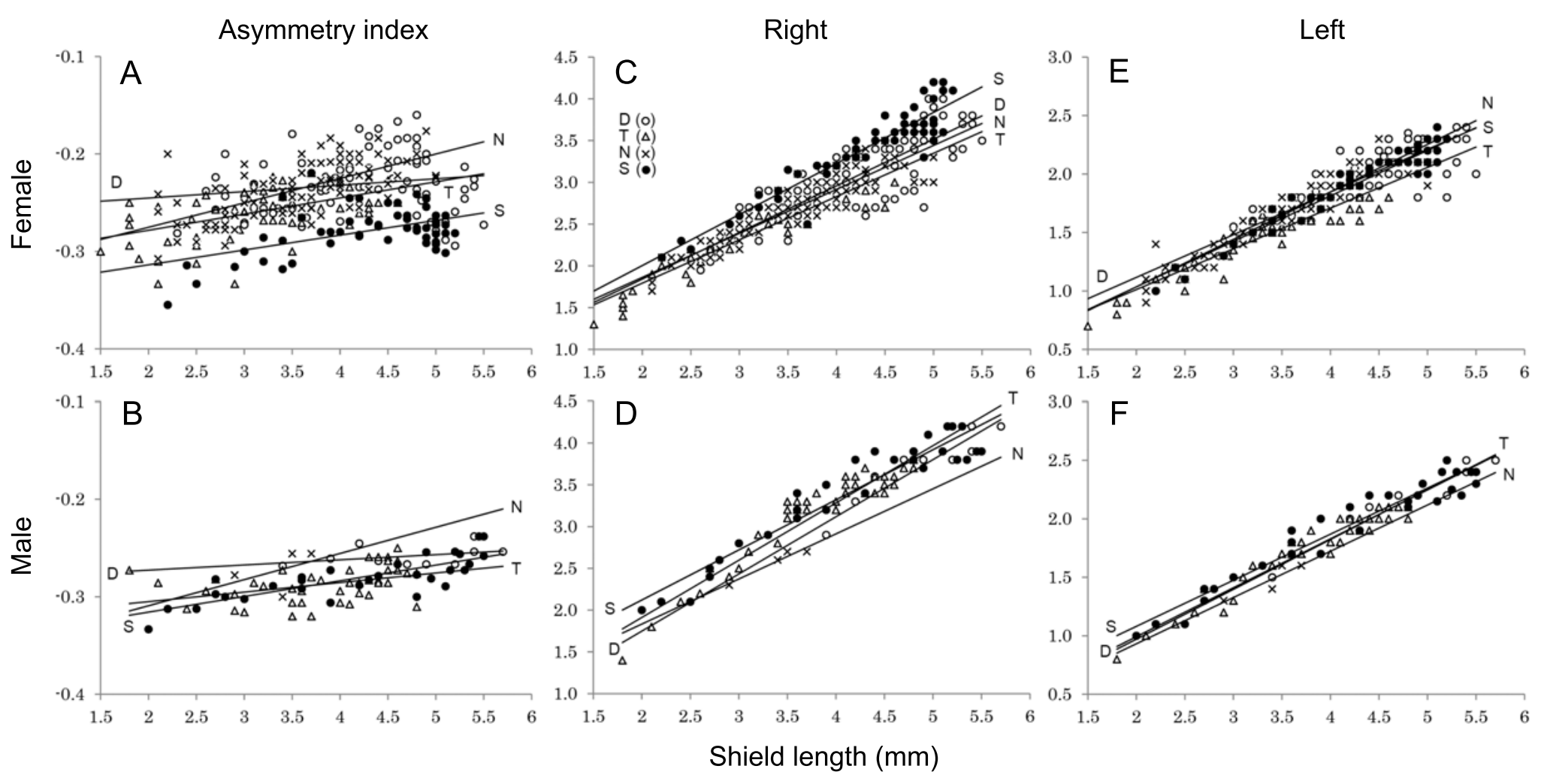




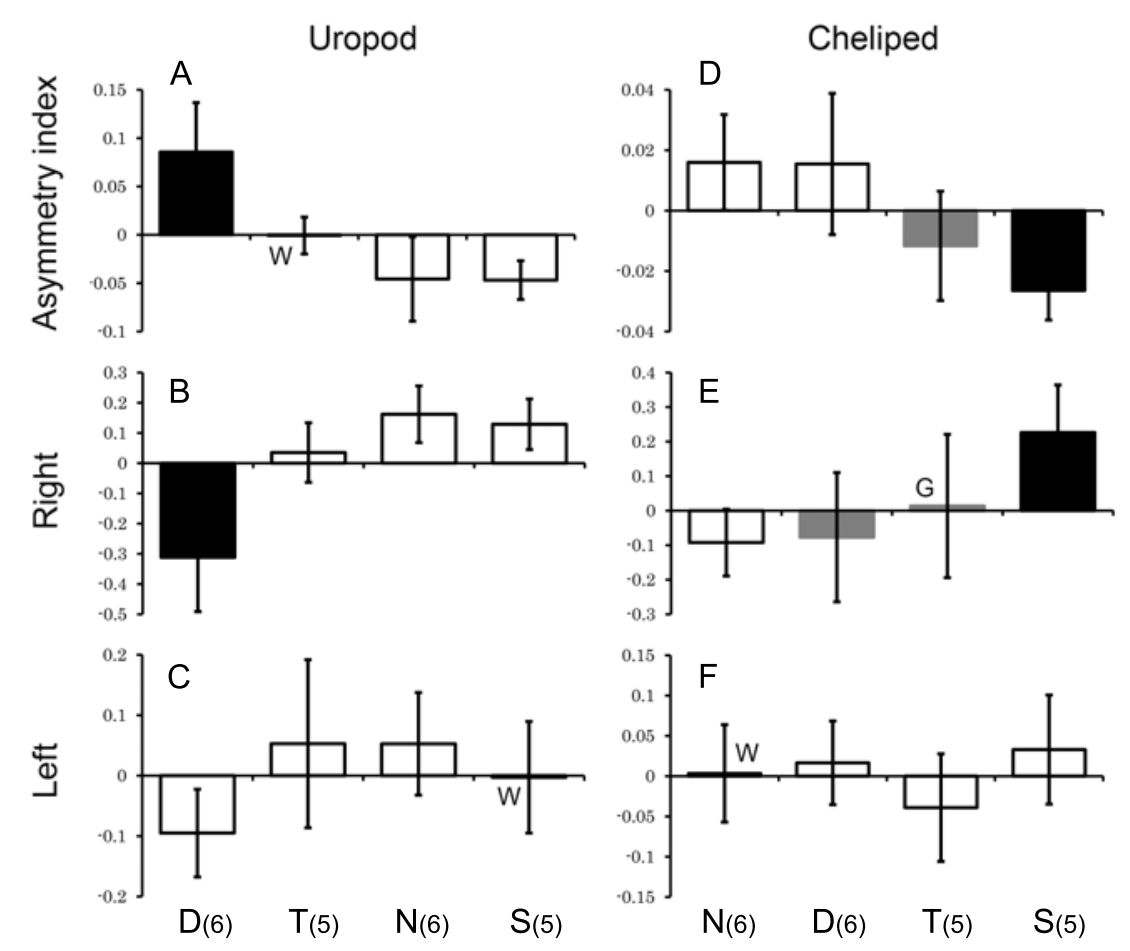




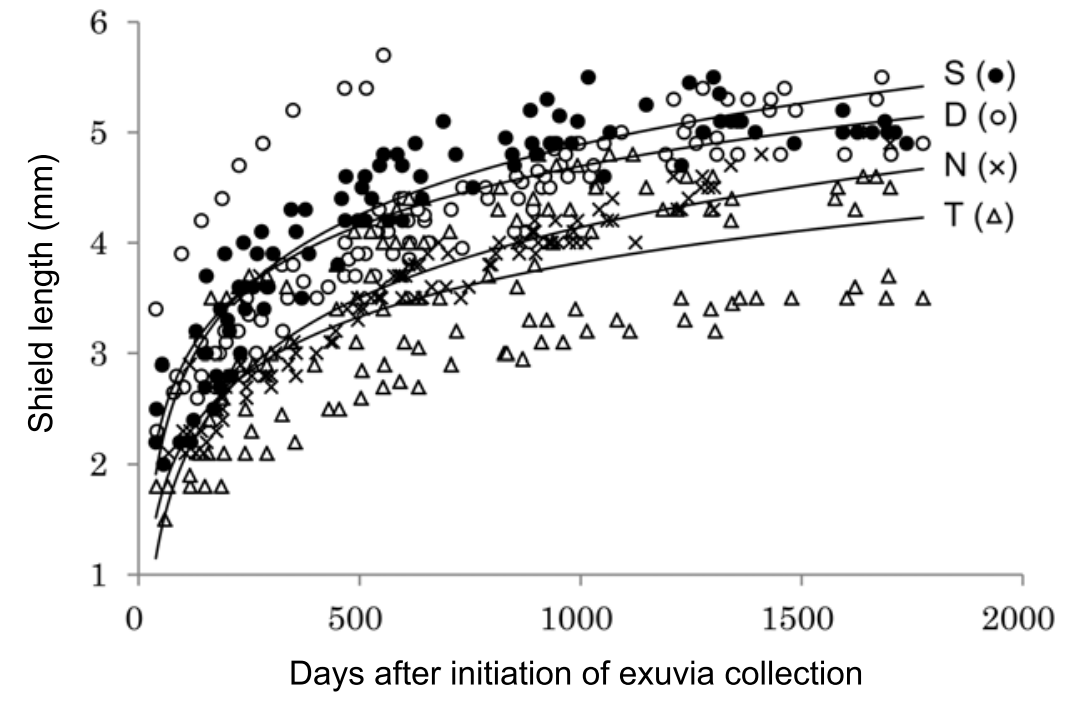




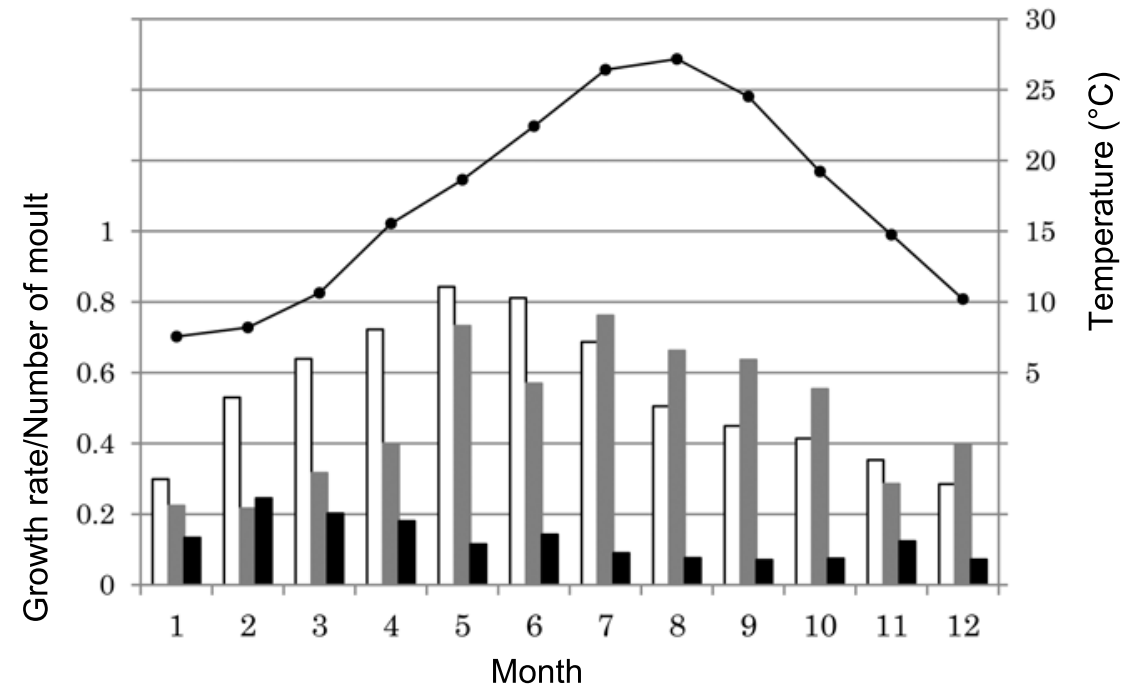

